CZASOPISMO INŻYNIERII LA¿OWEJ, ŚRODOWISKA I ARCHITEKTURY JOURNAL OF CIVIL ENGINEERING, ENVIRONMENT AND ARCHITECTURE JCEEA, t. XXXIV, z. 64 (3/II/17), lipiec-wrzesień 2017, s. 257-272, DOI:10.7862/rb.2017.170

\author{
Maciej PIEKARSKI ${ }^{1}$ \\ Aleksandra PROKOPSKA ${ }^{2}$ \\ Ewelina GOTKOWSKA ${ }^{3}$ \\ Anna PROKOP ${ }^{4}$
}

\title{
KONCEPCJA INTEGRACJI OGRODU MIEJSKIEGO W RZESZOWIE Z PRZESTRZENIĄ PUBLICZNĄ STAREGO MIASTA
}

\begin{abstract}
Opracowanie przedstawia koncepcję przedłużenia traktu spacerowego, obejmującego Rynek, ulice Kościuszki i 3-go Maja oraz aleje Lubomirskich i Pod Kasztanami w Rzeszowie, w kierunku Ogrodu Miejskiego przy ul. Dąbrowskiego. Koncepcję opracowano w celu włączenia do jednolitego obszaru przestrzeni publicznej mało eksponowanych obszarów o wybitnych w skali Rzeszowa wartościach architektonicznych, historycznych i przyrodniczych. Trasę nowoprojektowanego traktu spacerowego przewiduje się poprowadzić wzdłuż ulicy Kraszewskiego, a po przekroczeniu ul. Unii Lubelskiej prostopadle do ulicy Reformackiej, i dalej prosto w kierunku Ogrodu Miejskiego. W pracy dokonano analizy Ogrodu Miejskiego oraz najbardziej znaczących obiektów położonych wzdłuż projektowanego odcinka szlaku spacerowego. Zwrócono uwagę na możliwości wykorzystania ich walorów dla realizacji istotnych funkcji przestrzeni publicznej. Przedstawiono plan niezbędnych zmian w przestrzeni architektonicznej, wraz z propozycjami konkretnych rozwiązań w tym zakresie. Przedłożono propozycję osłabienia przeszkody na trasie traktu, jaką stanowi ruchliwa ul. Lisa-Kuli, proponując przeniesienie części ruchu samochodowego do tunelu wybudowanego pod obecną jezdnią, a tym samym przywrócenie ulicy jej pierwotnej skali urbanistycznej. Wymienione propozycje zostały zaprezentowane w opracowaniach urbanistycznych oraz rysunkach
\end{abstract}

\footnotetext{
${ }^{1}$ Autor do korespondencji/corresponding author: Maciej Piekarski, Politechnika Rzeszowska, Zakład Projektowania Architektonicznego i Grafiki Inżynierskiej, al. Powstańców Warszawy 12, 35-959 Rzeszów; tel.: 17865 1839; e-mail: mgpiekar@prz.edu.pl

2 Aleksandra Prokopska, Politechnika Rzeszowska, Zakład Projektowania Architektonicznego i Grafiki Inżynierskiej, al. Powstańców Warszawy 12, 35-959 Rzeszów; tel.: 17865 1839; e-mail: aprok@prz.edu.pl

3 Ewelina Gotkowska, Politechnika Rzeszowska, Zakład Projektowania Architektonicznego i Grafiki Inżynierskiej, al. Powstańców Warszawy 12, 35-959 Rzeszów; e-mail: d325@stud.prz.edu.pl

4 Anna Prokop, Politechnika Rzeszowska, Zakład Projektowania Architektonicznego i Grafiki Inżynierskiej, al. Powstańców Warszawy 12, 35-959 Rzeszów; tel.: 17865 1492; e-mail: a.prokop@prz.edu.pl
} 
wizualizacyjnych. Projekt przedłużenia traktu spacerowego w obszarze historycznego centrum, wychodzi naprzeciw potrzebom miasta Rzeszowa. W mieście występuje deficyt właściwie zagospodarowanej przestrzeni publicznej, odpowiedniej dla realizacji aktywności społecznej mieszkańców oraz kształtującej ich tożsamość i poczucie przynależności do lokalnej społeczności.

Słowa kluczowe: Rzeszów, przestrzeń publiczna, układ urbanistyczny, rewitalizacja, krajobraz kulturowy

\section{Wprowadzenie}

Rzeszów jest miastem, które w ciągu ostatnich 80 lat uległo przekształceniu $\mathrm{z}$ małego miasteczka w istotny ośrodek administracyjny, gospodarczy i naukowy. Konsekwencją jest wielokrotny wzrost obszaru oraz liczby mieszkańców miasta. Naturalną potrzebą każdej lokalnej społeczności jest posiadanie przestrzeni publicznej, tj. miejsca realizacji bezpośrednich kontaktów pomiędzy uczestnikami życia społecznego, dostępnego dla wszystkich zainteresowanych [11]. Jeżeli przestrzeń ta odzwierciedla fizycznie historię i tradycję miasta, wpływa poprzez własną tożsamość na tożsamości członków użytkującej ją wspólnoty [12].Z powyższych względów, najbardziej wartościową przestrzenią publiczną są place, ulice, parki i skwery na obszarze historycznego centrum miejscowości, zapewniające dostęp do zabytków, placówek kulturalnych, lokali gastronomicznych itp. Dla realizacji swoich funkcji powinna ona pozostawać we właściwej proporcji do wielkości miasta i liczby jego mieszkańców.

Problemami Rzeszowa są niekorzystny stosunek powierzchni przestrzeni publicznej do wielkości miasta oraz zdecydowana przewaga w jego krajobrazie elementów współczesnych nad posiadającymi znamiona historyczne. W związku z tym, istotne jest, aby zrewitalizować dla wypełniania funkcji przestrzeni publicznej jak największą część historycznego Rzeszowa, a zwłaszcza obszary o ugruntowanej niegdyś pozycji i wciąż wybitnych walorach krajobrazowych. Miejscem szczególnie predestynowanym z uwagi na jego przeszłość i wartość przyrodniczą jest Ogród Miejski przy ul. Dąbrowskiego, który z powodu swojego obecnego stanu oraz braku przestrzennej spójności z terenami intensywnie uczęszczanymi, jest stosunkowo mało popularny wśród mieszkańców Rzeszowa. Autorzy niniejszego opracowania dostrzegli możliwość połączenia ogrodu z historycznym centrum miasta szlakiem spacerowym, wśród obiektów o wyjątkowych w skali Rzeszowa walorach i znaczeniu. Trasa szlaku została wytyczona z myślą o maksymalnie możliwym, w realnych okolicznościach, odseparowaniu ruchu pieszego od uciążliwości ruchu samochodowego.

W przedstawianym opracowaniu, z uwagi na wymóg jego objętości, autorzy dokonali jedynie analizy uwarunkowań, w jakich pozostaje przestrzeń urbanistyczna na obszarze stanowiącym przedmiot zainteresowań oraz przedstawili wyciągnięte z niej konkluzje. Jest to zaledwie wstępna, lecz mająca istotne znaczenie faza procesu projektowego $[14,15]$. 


\section{Przeszłość, teraźniejszość i potencjał rewitalizacyjny Ogrodu Miejskiego}

Historia Ogrodu Miejskiego sięga początku XVIII wieku i jest związana ze znajdującym się wówczas w sąsiedztwie klasztorem Reformatów. W początkach istnienia ogród był dostępny wyłącznie dla zakonników, jako teren przeznaczony na rekreację i kontemplację oraz miejsce uprawy warzyw, ziół i kwiatów na użytek klasztoru. Oprócz alejek i bogatego drzewostanu, w ogrodzie znajdowały się altany i kaplice, a także stawy do hodowli ryb [6]. Zmiana przeznaczenia ogrodu wiązała się z kasacją klasztoru dokonaną w roku 1787. Została ona urzeczywistniona dopiero w 1871 roku, kiedy nastąpiło przejęcie ogrodu przez miasto uchwałą rady miejskiej [16].

Ogród, od momentu otwarcia dla publiczności stał się letnim salonem miasta. Od lat osiemdziesiątych XIX wieku odbywały się tam koncerty orkiestr. Opłaty jakie próbowali pobierać muzycy za wstęp do ogrodu w trakcie występów, wywołały spór o jego publiczną dostępność, która zdobyła sobie w krótkim czasie dużą popularność [15].W końcu XIX wieku w ogrodzie znajdowały się oranżeria, kręgielnia, strzelnica i restauracja [4]. W początku wieku XX, piłkarze Resovii rozgrywali regularne mecze piłki nożnej [8]. Występy orkiestr i festyny organizowane były także w okresie międzywojennym. Sprzyjała temu obecność działalności gastronomicznej. Ostatnim lokalem o takiej funkcji była istniejąca do lat 60-tych XX wieku kawiarnia nazywana „Tramwajem”.

W okresie po II wojnie światowej ogród był poddany kilkakrotnie rewitalizacjom, których rezultaty zostały zniweczone. W roku 1952 zbudowano fontannę, upiększoną rzeźbami antycznych postaci, nieco później dokonano korekty stawu i wyłożono jego brzeg granitowymi płytami, montując w nich wodotryski. $\mathrm{W}$ jednej z kwater ogrodu urządzono rosarium. Wymienione elementy uległy w latach późniejszych likwidacji, a jedynymi efektami modernizacji powojennych są: plac zabaw z górką saneczkową oraz wyasfaltowane alejki, których wartość dla podtrzymania tożsamości ogrodu jest wątpliwa. Szkodą dla układu przestrzennego było wybudowanie w obrębie ogrodu budynku, przeznaczonego dla Miejskiego Przedsiębiorstwa Gospodarki Komunalnej, po roku 1989 przekazanego na potrzeby kościelne. Na tle dokonanej degradacji ogrodu, pozytywnymi akcentami było odsłonięcie w 2002 roku pomnika Juliusza Słowackiego, uwieńczające ideę zainicjowaną wmurowaniem kamienia węgielnego $\mathrm{w}$ roku 1927 oraz realizacja fontanny w rejonie ul. Dąbrowskiego wraz z okalającym ją skwerem i rzeźbami. Fontanna i rzeźby miały przywrócić ogrodowi atmosferę z lat 60. XX wieku, ale zdaniem autorów, ich lokalizacja, na skraju założenia kompozycyjnego oraz obok ruchliwej ulicy, jest nieudana.

W dniu dzisiejszym Ogród Miejski znajduje się w stanie zaniedbanym, ale kwaterowy układ przestrzenny oraz cenny drzewostan, umożliwiają rewitalizację w kierunku uczynienia go atrakcyjnym miejscem rekreacji. W ogrodzie znajdują się okazy drzew pamiętających czasy Reformatów, a średni wiek drzewo- 
stanu wynosi ok. 100 lat [17]. Oprócz popularnych gatunków rosną m.in. kasztan jadalny, platan klonolistny, brzoza czarna, jodła kalifornijska, wiąz górski i cis japoński [9]. Przywrócenie ogrodowi funkcji „letniego salonu Rzeszowa” wymaga realizacji szeregu zamierzeń, w tym przede wszystkim jego ogrodzenia, organizacji gastronomii i toalet, odbudowy stawu, rosarium itp.

\section{Analiza przestrzeni urbanistycznej na obszarze pomiędzy ze- społem Zamku Lubomirskich i Ogrodem Miejskim}

Dominantą architektoniczną centrum Rzeszowa, położoną w bliskości Ogrodu Miejskiego jest zespół Zamku Lubomirskich. W skład zespołu wchodzą XVII wieczne fortyfikacje bastionowe wraz z fosą oraz usytuowany wewnątrz założenia obronnego gmach sądu, zbudowany w pierwszych latach XX wieku, w miejscu wcześniejszego zamku. Otoczenie zespołu zamkowego stanowi najcenniejszą krajobrazowo część starego Rzeszowa, której blasku dodaje obecność w pobliżu barokowego Pałacu Letniego Lubomirskich, secesyjnych willi przy Alei Pod Kasztanami, modernistycznej zabudowy ul. Dekerta oraz starego drzewostanu.

Aleje Lubomirskich i Pod Kasztanami, okalające z dwóch stron zespół zamkowy, stanowią najdalej wysunięte fragmenty ciągu spacerowego obejmującego Rynek oraz ulice Kościuszki, Grunwaldzką i 3 Maja. Przestrzeń wokół zespołu zamkowego cieszy się sporym zainteresowaniem mieszkańców oraz turystów. Zostało ono spotęgowane rozpoczęciem funkcjonowania w roku 2015 fontanny multimedialnej, a dalszy wzrost jest prawdopodobny po spodziewanym uruchomieniu lokali gastronomicznych w Pałacu Letnim oraz w planowanym do odbudowy budynku dawnej kordegardy. Ewentualna realizacja zapowiedzi przekazania budynku sądu na cele kulturalne wzmoże wykorzystywanie tej przestrzeni dla funkcji rekreacyjnej i turystycznej. Wobec aktualnych ograniczeń urbanistycznych, w tym szczególnie okolenia zespołu zamkowego od strony zachodniej i południowej ciągiem ulic o znacznym natężeniu ruchu samochodowego oraz obecności skomplikowanego węzła komunikacyjnego w obrębie placu Śreniawitów, rozpatrywany obszar stanowi kraniec przestrzeni publicznej w centrum Rzeszowa. Nawet ciekawe projekty rozszerzenia tej przestrzeni nie przewidują ekspansji poza wspomniany ciąg ulic [10].

Wspólną cechą otoczenia zespołu Zamku Lubomirskich oraz Ogrodu Miejskiego jest oprócz historycznego rodowodu, obecność starego drzewostanu. Miejsca są oddalone w linii prostej od siebie o niespełna $500 \mathrm{~m}$, zaś teren pomiędzy nimi jest $\mathrm{w}$ przeważającej części wypełniony zabudową pochodzącą z początku XX wieku i starszą, wpisaną w większości do ewidencji zabytków [7] (rys. 1). Można uznać, że przestrzeń ta jest spójna krajobrazowo z otoczeniem zespołu zamkowego. Niski stopień jej wykorzystania jako przestrzeni publicznej wynika z braku czytelnych osi ruchu pieszego i rowerowego. Obecnie, ruch pieszych odbywa się chodnikami wzdłuż ulic, a mankamentami są wąskość 
chodników, spotęgowana dopuszczeniem na nich możliwości parkowania samochodów, duże natężenie ruchu ulicznego, przekładające się na hałas oraz zanieczyszczenie powietrza, a także konieczność kluczenia wobec braku prostej drogi. Jazda rowerem wymaga poruszania się po jezdniach ulic.

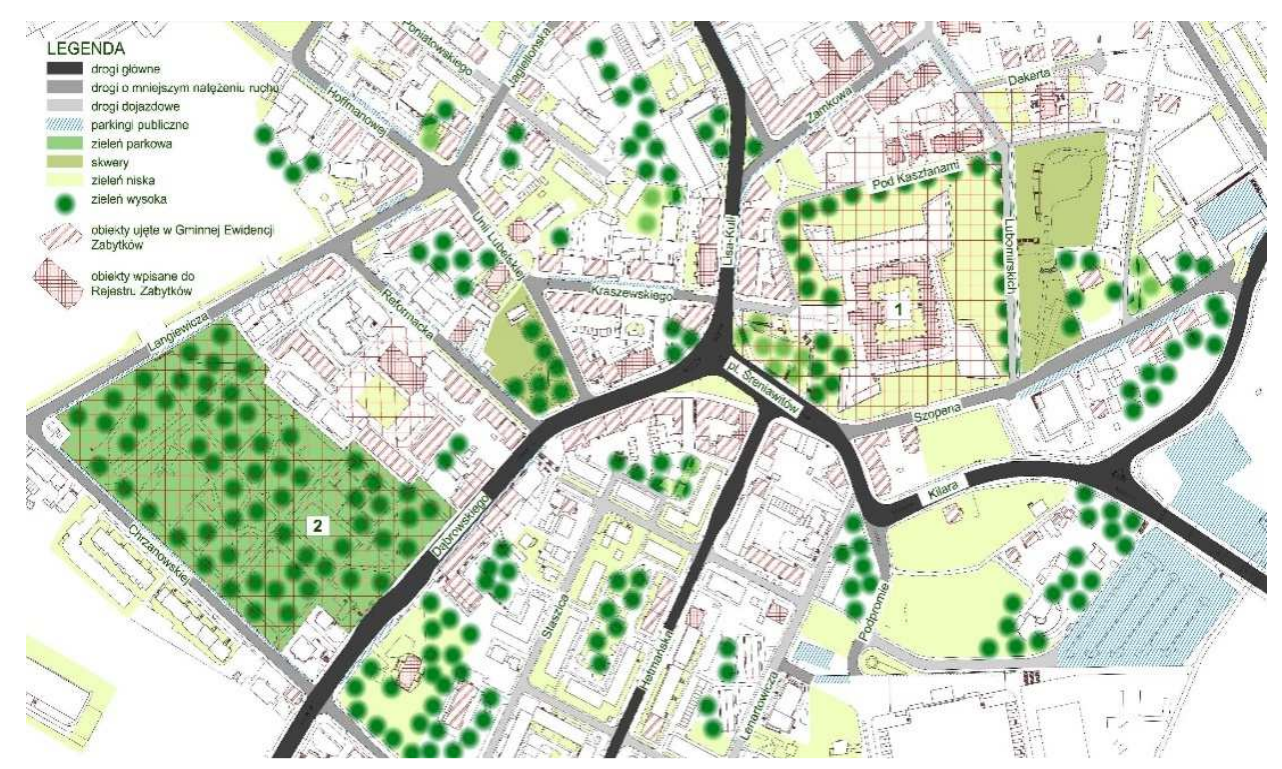

Rys. 1. Analiza przestrzeni urbanistycznej na obszarze pomiędzy zespołem Zamku Lubomirskich (1) i Ogrodem Miejskim (2) (rysunek autorów)

Fig. 1. Analysis of the urban space in the area between the Lubomirski Castle Complex (1) and the City Garden (2) (authors' drawing)

\section{Charakterystyka proponowanej trasy traktu spacerowego łączącego zespół Zamku Lubomirskich z Ogrodem Miejskim}

Motywem artykułu jest pomysł połączenia dwóch miejsc o wybitnych walorach krajobrazowych, jakimi są otoczenie zespołu Zamku Lubomirskich oraz Ogród Miejski, szlakiem spacerowym, poprowadzonym wzdłuż ulicy Kraszewskiego, a następnie prostopadle do ulic Unii Lubelskiej i Reformackiej, przez nowe wejście do ogrodu od strony północno-wschodniej. Taki przebieg trasy jest racjonalny z tego powodu, że oprócz przecięcia z ruchliwą ulicą Lisa-Kuli, przebiega ona przez tereny o względnie niskim natężeniu hałasu ulicznego. Na pewnym odcinku wykorzystuje już ukształtowane przestrzennie wnętrze ulicy Kraszewskiego, zaś na pozostałej części teren, wymagający przeobrażeń w celu wyodrębnienia korytarza dla ruchu pieszego i rowerowego, ale nasycony obiektami architektonicznymi, których ranga i aktualne lub planowane przeznaczenie mogą stymulować kreację przestrzeni publicznej (rys. 2.). 


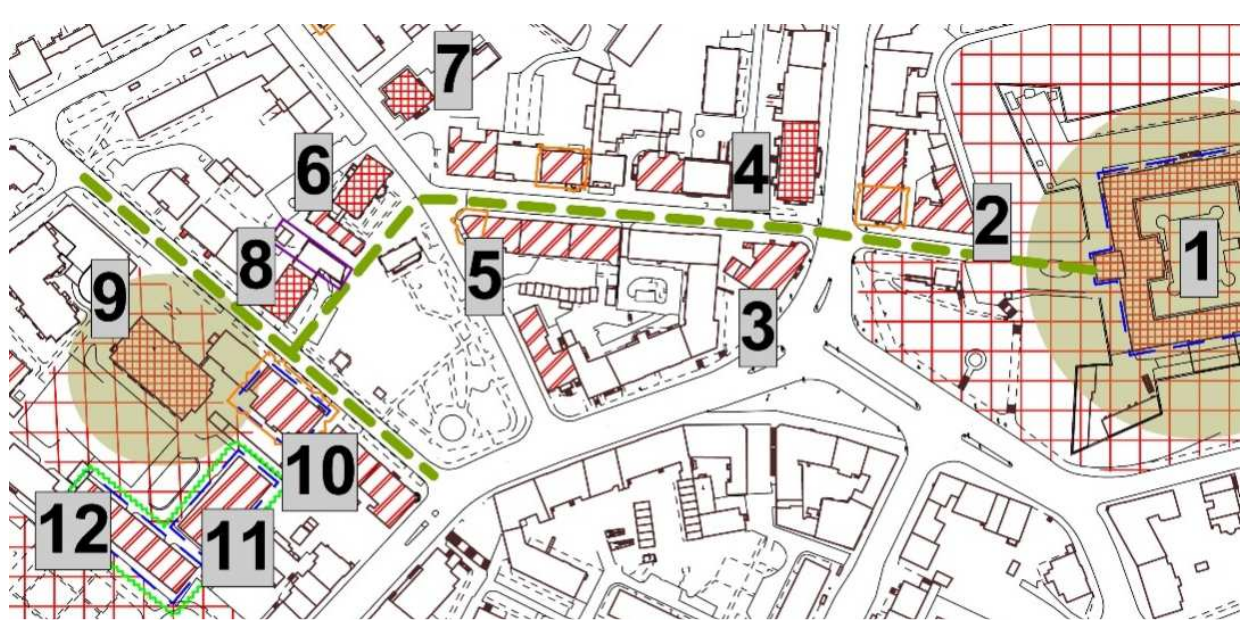

Rys. 2. Trasa szlaku łączącego zespół Zamku Lubomirskich z Ogrodem Miejskim oraz położone wzdłuż niego budynki o szczególnej wartości kulturowej: 1) zespół Zamku Lubomirskich, 2) kamienica Różyckich, 3) kamienica Dzierżyńskich, 4) dworek Bieniaszewskich, 5) dom-statek, 6) dworek Skrzyńskich, 7) dawny szpital Fundacji dr Hanasiewicza, 8) dwór Piątkowskiego, 9) kościół garnizonowy, 10) budynek piekarni, 11) ruina magazynu, 12) zabytkowy magazyn (rysunek autorów)

Fig. 1. Route linking the Lubomirski Castle complex with the Municipal Garden and the buildings located along it with distinctive cultural value: 1) Lubomirski Castle Complex, 2) Różycki family apartment house, 3) Dzierżyński family apartment house, 4) Bieniaszewski family manor house, 5) house-to-ship, 6) Skrzynski family manor house, 7) former hospital of drHanasiewicz Foundation, 8) Piątkowski manor house, 9) garrison church, 10) bakery building, 11) warehouse ruin, 12) historic warehouse (authors' drawing)

Umownym początkiem trasy jest plac przed wejściem do budynku sądu, który mimo ograniczenia dostępu do jego części, umożliwia bliską percepcję dominującej wieży, stanowiącej oryginalny fragment pierwotnego zamku. Obok znajduje się tzw. kamienica Różyckich, która wyróżnia się formą narożnych okien zrealizowanych w stylistyce ,art nouveau”. Datowana na pierwszą dekadę XX wieku, intryguje ponadto ornamentyką zewnętrznej oraz wewnętrznej sztukaterii i metaloplastyki. Jej historia, podobnie jak historia sąsiedniej kamienicy, wplata się w XX-wieczną historię Polski. W czasach okupacji siedzibę miało tu Gestapo, zaś zaraz po wojnie Urząd Bezpieczeństwa. W piwnicach obu kamienic były urządzone cele, w których przetrzymywano aresztowanych.

Ukierunkowanie trasy na ulicę Kraszewskiego wzmacnia ekspozycję obiektów usytuowanych u wlotu tej ulicy. Budynek po lewej stronie to pochodząca z pierwszej dekady XX wieku kamienica Dzierżyńskich. Jego prosta forma jest urozmaicona narożną wieżą oraz pionowym podziałem elewacji na części o zróżnicowanej kolorystyce i fakturze. Po prawej stronie znajduje się tzw. dworek Bieniaszewskich, datowany na okres przed 1842 rokiem. Budynek wpisany do rejestru zabytków, stanowi przykład architektury rezydencjalnej, adaptowanej 
do otoczenia śródmiejskiego. Oba obiekty, ze względu na bliską krawędź jezdni, nie znajdują odpowiedniej ekspozycji dla obserwatorów przemieszczających się wzdłuż frontowych ścian budynków.

Zabudowa ulicy Kraszewskiego pochodzi z różnych okresów. Oprócz obiektów wpisanych do gminnej ewidencji zabytków (budynki o numerach 3, 4, 5, 6, 7 i 10), znajdują się budynki nowsze, których architektura nie narusza historycznego charakteru ulicy. Takimi obiektami są: prosty $\mathrm{w}$ formie budynek pod numerem 1, pochodzący $\mathrm{z}$ okresu wczesno-powojennego oraz niedawno modernizowane budynki o numerach 4a i 8. Dwa ostatnie pozostają w harmonii $\mathrm{z}$ otoczeniem dzięki umiejętnie dobranej kompozycji i kolorystyce elewacji.

Zamknięciem kompozycyjnym ulicy Kraszewskiego, widzianym przez obserwatora podążającego w kierunku Ogrodu Miejskiego, jest dworek Skrzyńkich. Dworek pochodzący z I ćwierci XIX wieku zachował pierwotną bryłę i skromny wystrój architektoniczny. Jego wyrazistość w krajobrazie jest osłabiona obecnością drzew rosnących w bliskiej odległości od elewacji frontowej.

Atrakcyjność skrzyżowania ulic Kraszewskiego i Unii Lubelskiej wynika przede wszystkim z powodu architektury narożnego budynku pod numerem 7 , określanego nazwą ,dom-statek” [3].To jeden z najciekawszych w Rzeszowie budynków okresu międzywojennego. W obiekcie zlokalizowanym na działce w kształcie ostrego klina architekt zaokrąglił krawędź narożną, nawiązując w modny wówczas sposób do architektury transatlantyków.

W perspektywach otwierających się ze skrzyżowania na ulicę Unii Lubelskiej również zarysowują się budynki o intrygującej architekturze. Widok w kierunku ulicy Dąbrowskiego jest domknięty obrazem kamienicy numer 7, pochodzącej sprzed 1903 roku, ostatnio odrestaurowanej. W perspektywie w kierunku ulicy Jagiellońskiej wyróżnia się willa Hanasiewicza, datowana na rok 1910, mieszcząca dawniej Szpital dla Dzieci im. Dzieciątka Jezus, zaś obecnie Pogotowie Opiekuńcze dla Nieletnich. Obecność krat w oknach budynku obniża estetykę obiektu, wpisanego do rejestru zabytków. Najciekawsze jest otwarcie widokowe ulicy Kraszewskiego, z dominantą w postaci wieży budynku sądu.

Obszar pomiędzy ulicami Unii Lubelskiej i Reformacką jest ogrodzony, porośnięty starodrzewem i pełni funkcję placu zabaw dla dzieci. Walorami terenu, oprócz obecności zieleni, są ekspozycje obiektów architektonicznych. Perspektywa w kierunku północno-wschodnim pozwala obcować z widokiem budynku przy ul. Kraszewskiego 7, jak również urokliwego budynku przy ul. Unii Lubelskiej 2 pochodzącego z 1929 roku. Na pierwszym planie perspektywy północno-zachodniej sytuuje się dwór Piątkowskiego, budynek z I połowy XVIII wieku, wpisany do rejestru zabytków, jeden z najstarszych i najlepiej zachowanych w Rzeszowie obiektów architektury świeckiej. Obiekt jest własnością prywatną, lecz pieczołowicie pielęgnowany, stanowi siedzibę placówek edukacyjnych. W oficynie, znajduje się siedziba Teatru Przedmieście, odnoszącego liczne sukcesy na forum ogólnopolskim i międzynarodowym. 
W końcowym odcinku trasa traktu spacerowego została wytyczona przez tereny pokryte zabudową, której intensywność zmusza do naruszenia struktury istniejących obiektów. W pierzei ulicy Reformackiej, na trasie traktu, stoi budynek mieszczący piekarnię datowany na początek XX wieku. Budynek należący dawniej do wojska, mimo że utracił sporo z pierwotnego wyglądu, zachował pierwotną funkcję. $Z$ tyłu za nim znajduje się ruina spalonego w 1994 roku magazynu wojskowego, dobrze widoczna $\mathrm{z}$ terenu okalającego pobliski kościół garnizonowy. Ostatnim obiektem, usytuowanym w poprzek wytyczonej trasy, jest parterowy magazyn, którego południowo-zachodnia ściana znajduje się w istocie w granicy Ogrodu Miejskiego.

\section{Zamierzenia umożliwiające realizację koncepcji}

W chwili obecnej, ani ulica Kraszewskiego, ani tym bardziej pozostałe rozpatrywane tereny nie cieszą się znaczącą popularnością wśród pieszych i rowerzystów. Intencją autorów jest wygenerowanie ruchu, nie jako alternatywy dla przemieszczania się po dotychczasowych szlakach, ale ruchu rekreacyjnego. Według uznanych poglądów [5], warunkiem jego spontanicznego pojawienia się

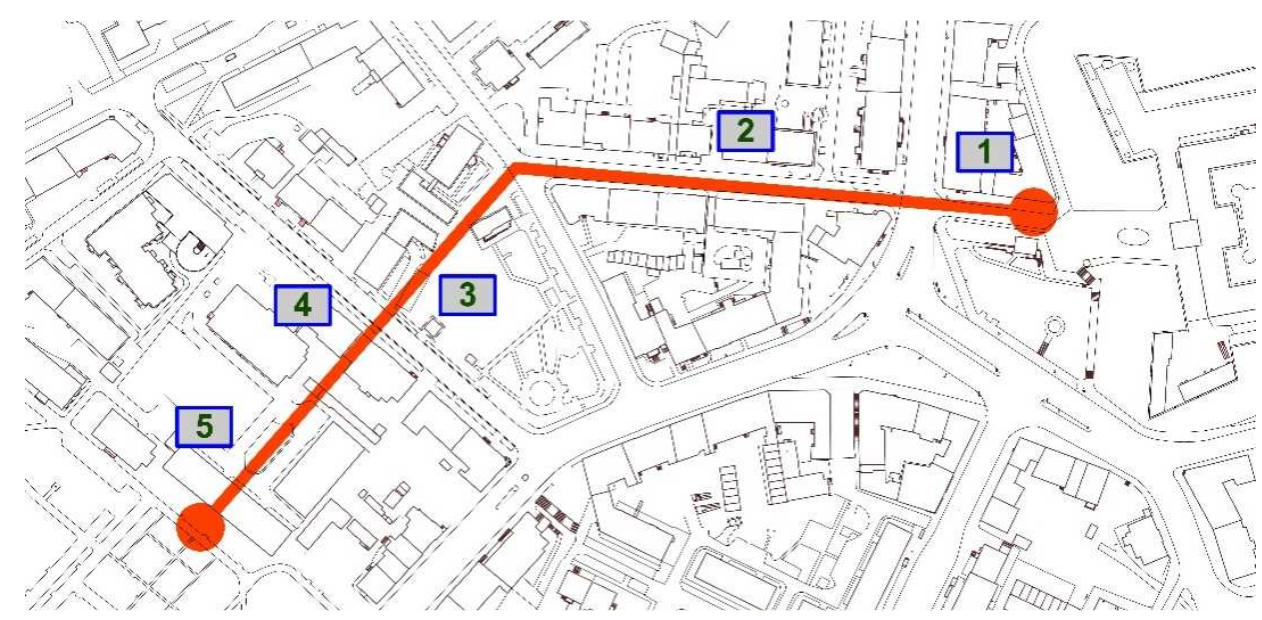

Rys. 3. Zamierzenia do realizacji w celu połączenia zespołu Zamku Lubomirskich z Ogrodem Miejskim traktem spacerowym: 1) osłabienie przeszkody w postaci ul. Lisa-Kuli, 2) modernizacja ul. Kraszewskiego, 3) zmiana zagospodarowania terenu pomiędzy ul. Unii Lubelskiej i ul. Reformacką, 4) adaptacja piekarni na budynek przechodni, 5) adaptacja zabytkowego magazynu (rysunek autorów).

Fig. 3. Projects planned for the purpose of merging the Lubomirski Castle with the Municipal Garden by a walking route: 1) weakening of the obstacle in the form of Lisa-Kuli street, 2) modernization of Kraszewski street, 3) change of land use between Lublin Union and Reformacka streets, 4) adaptation of the bakery to the passage building, 5) adaptation of the historic warehouse (authors' drawing). 
jest odpowiednia aranżacja przestrzeni miejskiej. Kluczowymi wyzwaniami jakie muszą być podjęte jest maksymalnie możliwe ograniczenie ruchu samochodowego, odseparowanie go od ruchu pieszego i rowerowego oraz takie zagospodarowanie otoczenia architektonicznego, aby stwarzało spacerowiczom nie tylko okazję, ale wręcz pokusę do zatrzymania się, a tym samym możliwość konstatacji walorów krajobrazu kulturowego. Urzeczywistnienie koncepcji wymaga realizacji szeregu przedsięwzięć inwestycyjnych o różnym stopniu złożoności. Miejsca kluczowych zamierzeń proponowanych przez autorów zostały oznaczone na mapie (rys. 3.), zaś same działania wyjaśnione poniżej.

\subsection{Osłabienie przeszkody komunikacyjnej w postaci ul. Lisa-Kuli}

Istotną przeszkodą utrudniającą integrację ulicy Kraszewskiego z otoczeniem zespołu zamkowego jest przebiegająca poprzecznie ulica Lisa-Kuli, której jezdnia posiada aż cztery pasy ruchu i na której występuje bardzo duże natężenie ruchu samochodowego oraz tworzą się korki, zwłaszcza na kierunku: aleja Cieplińskiego - most Zamkowy. Rozdzielenie przecinających się szlaków ruchu pieszego i kołowego, poprzez budowę kładki lub przejścia podziemnego jest sprzeczne z aktualnymi tendencjami urbanistycznymi [5], a ponadto nie ograniczy intensywnego eksploatowania ulicy, niekorzystnego z punktu widzenia zamiaru eksponowania jej krajobrazu architektonicznego. Obiektywną trudnością jest dodatkowo brak miejsca wystarczającego dla rozmieszczenia schodów lub wind, jak również utrata atrakcyjności przez perspektywę ulicy Kraszewskiego, w wyniku przesłonięcia przez kładkę dominującej w niej wieży zamkowej, lub pozbawienie na pewnym odcinku trasy możliwości wizualnego odbioru krajobrazu architektonicznego, w przypadku realizacji przejścia podziemnego.

Alternatywą dla przeniesienia na inny poziom ruchu pieszego jest skierowanie pod ziemię części ruchu samochodowego. Proponowane rozwiązanie (rys. 4.) sprowadza się do budowy pod jezdnią ulicy Lisa-Kuli tunelu, który na odcinku od skweru ks. Walentego Bala do placu Sreniawitów, przejąłby obustronny ruch kołowy na kierunku aleja Cieplińskiego - most Zamkowy. Przedkładany projekt nie ogranicza swojej skuteczności do usprawnienia ruchu pieszego i rowerowego na trasie pomiędzy zespołem Zamku Lubomirskich a Ogrodem Miejskim, ale stanowi propozycję kompleksowego rozwiązania problemu ruchu samochodowego w obrębie placu Śreniawitów.

Efektem urzeczywistnienia projektu byłoby przywrócenie ulicy Lisa-Kuli, we fragmencie stanowiącym dawną część ulicy Zamkowej, jej pierwotnej skali urbanistycznej, cechującej się węższą jezdnią, szerszymi chodnikami oraz znacznie mniejszym natężeniem ruchu kołowego. Kiedyś ulica ta stanowiła oś komunikacyjną prowadzącą głównie w kierunku ulicy Dąbrowskiego, a więc przebudowa przyczyniłaby się do przypomnienia pierwotnego układu urbanistycznego. Kompletnej destrukcji, spowodowanej zmianą rzeźby terenu oraz likwidacją istniejącego drzewostanu, uległby układ przestrzenny samego placu 


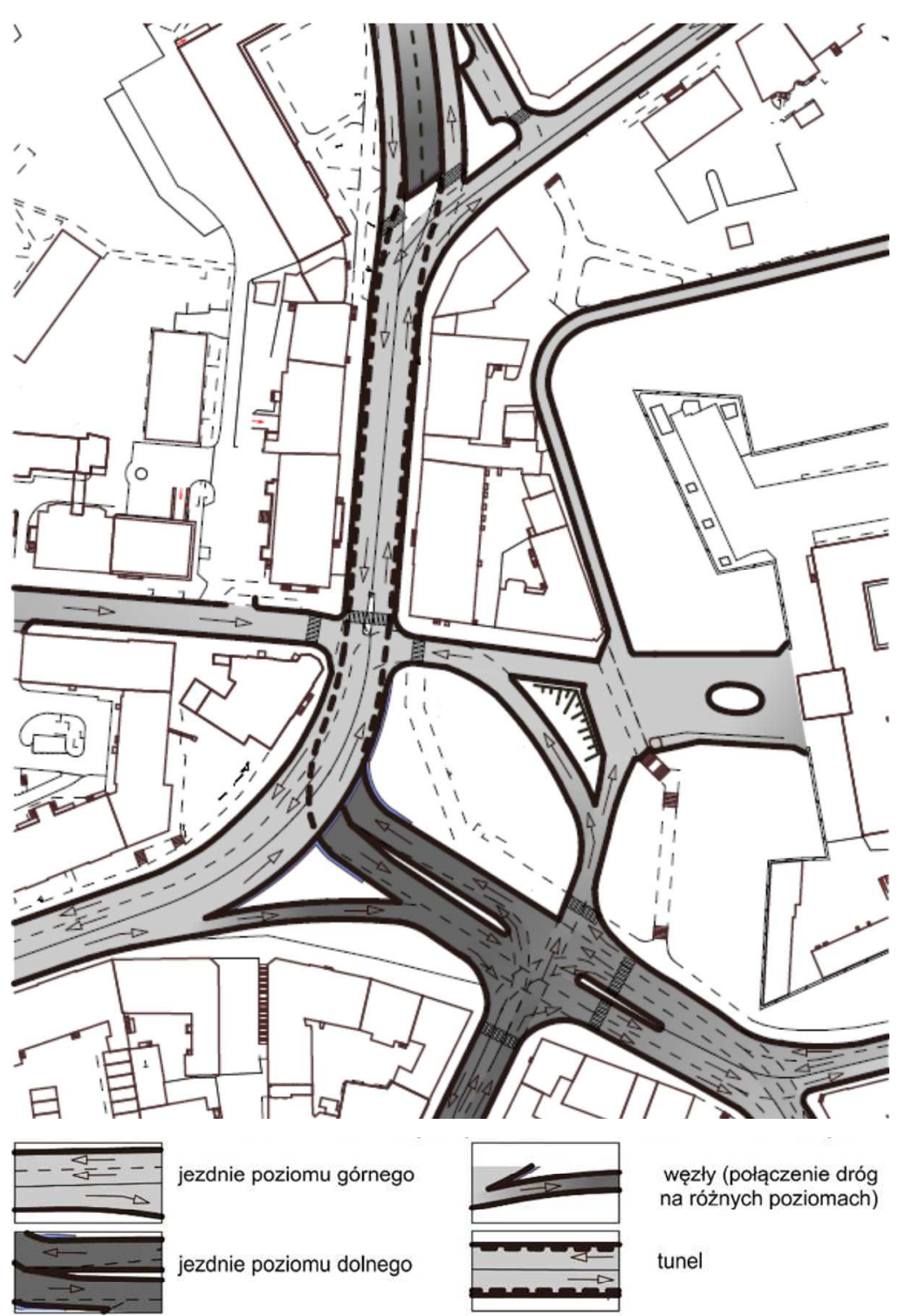

Rys. 4. Propozycja przebudowy układu komunikacyjnego w obrębie placu Śreniawitów (rysunek autorów)

Fig. 4. Proposal for the reconstruction of the communication system within the Śreniawitów Square (authors' drawing)

Śreniawitów. Konieczne byłoby zlikwidowanie toalety w północnej części placu oraz zmiana lokalizacji krzyża-pomnika „Ofiarom Komunizmu”. Atutem jego przeniesienia w inny rejon otoczenia zamkowego, np. na ulicę Szopena, byłaby 
większa swoboda dla organizowanych przy pomniku uroczystości. Radykalne i nie oparte w przeszłości zmiany w obrębie placu Śreniawitów mogłyby stanowić kanwę dla postulowanej [10] aranżacji zupełnie nowej przestrzeni publicznej i lepszej prezentacji w jej tle zespołu Zamku Lubomirskich.

\subsection{Przebudowa ulicy Kraszewskiego}

Przebudowa ulicy Kraszewskiego jest kwestią najmniej kłopotliwą. Ponieważ pełna eliminacja ruchu samochodowego wydaje się niemożliwa, proponuje się wydzielenie w przekroju poprzecznym ulicy szerokiego chodnika dla pieszych oraz ścieżki rowerowej, przyległych do pierzei północnej (rys. 5). Autorzy uważają, że zapewnienie poszczególnym grupom użytkowników oddzielnych i bezpiecznych korytarzy komunikacyjnych jest warunkiem koniecznym i wystarczającym dla wzmożenia ruchu pieszych i rowerzystów. Dlatego też, sugeruje się wprowadzenie między chodnikiem a ścieżką rowerową pasa buforowego, i umieszczenie w jego obrębie donic z zielenią oraz ławek.

Przymusem wynikającym ze zwężenia jezdni stałoby się ograniczenie ruchu samochodów do jednego kierunku. Proponuje się, aby był to kierunek od ulicy Unii Lubelskiej w stronę placu Śreniawitów. Z uwagi na ogólne założenie koncepcji, istotne jest, aby ruch rowerowy odbywał się w dwóch kierunkach. Takie rozwiązanie jest zgodne ze współczesnymi poglądami na organizowanie przestrzeni ulic w centrach miast [2]. W rezultacie zwężenia pasa dla samochodów, zostałyby zlikwidowane miejsca parkingowe po północnej stronie jezdni.

Zmianie charakteru ulicy powinno towarzyszyć rozszerzenie oferty społeczno-kulturalnej. Realizacja tego zamierzenia nie jest łatwa, ze względu na to, że większość budynków jest zajmowana przez mieszkania i urzędy. Wyjątek na tym tle stanowi modernistyczny budynek pod numerem 7, na parterze którego znajduje się lokal handlowy, stanowiący doskonałą lokalizację dla kawiarni, zaaranżowanej w przeżywającej renesans stylistyce „,art-deco”, właściwej dla okresu, w którym powstał ten budynek.

\subsection{Zmiana zagospodarowania terenu pomiędzy ul. Unii Lubelskiej i Reformacką}

Wytyczenie szlaku pomiędzy ulicami Unii Lubelskiej i Reformacką prostopadle do tych ulic i na przedłużeniu ulicy Kraszewskiego, wymaga budowy ciągu pieszo-rowerowego po terenie dzisiejszego placu zabaw (Rys. 6). Przeszkodą jest pawilon stanowiący siedzibę Międzyszkolnego Ośrodka Sportowego, który nie posiada istotnej wartości architektonicznej, wobec czego można uwzględniać jego wyburzenie. Dotychczasowa funkcja terenu, po dokonaniu zabiegów rewitalizacyjnych i nasadzeniu roślinności, która izolowałaby akustycznie obszar od ulicy Dąbrowskiego, może być podtrzymywana. Wskazana jest poprawa ekspozycji dworku Skrzyńskich oraz dworu Piątkowskiego, poprzez usunięcie przesłaniającej te budynki roślinności. Na placu przed dworem Piątkowskiego, sta- 
nowiącym obecnie parking, proponuje się lokalizację instalacji promującej działalność Teatru Przedmieście. Cały teren, ze względu na przestronność, zadrzewienie i otoczenie architektoniczne, jest dobrym miejscem dla zatrzymania pieszych, w związku z czym pożądana jest lokalizacja ławek.

a)

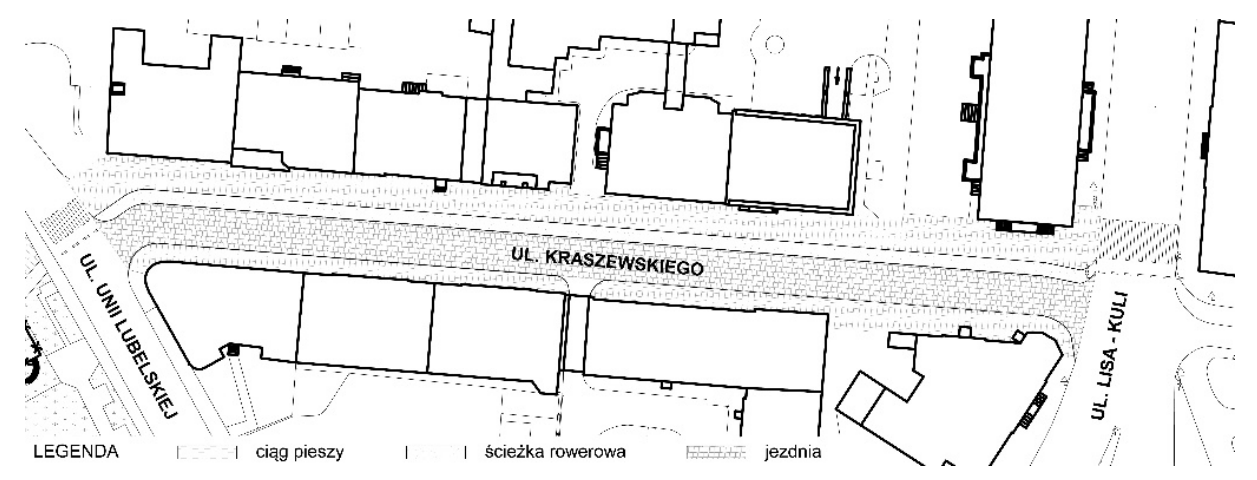

b)

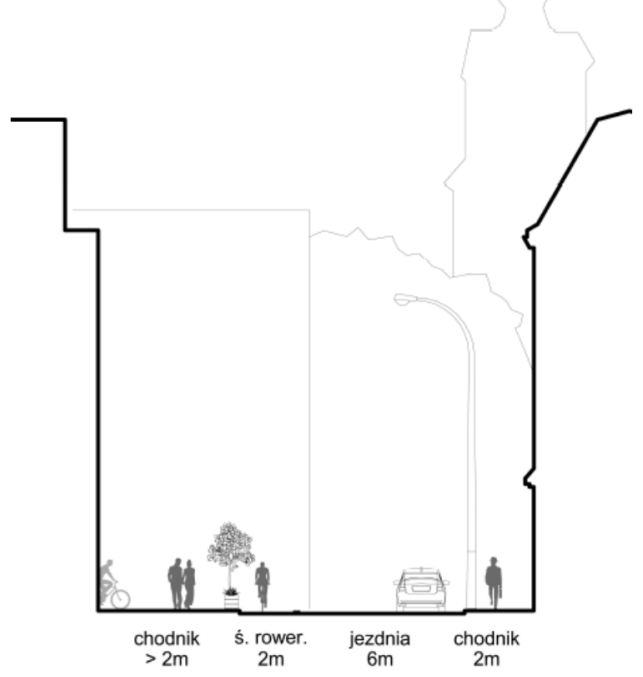

Rys. 5. Projekt modernizacji ul. Kraszewskiego: a) plan, b) przekrój poprzeczny (rysunki autorów)

Fig. 5. Project of reconstruction of Kraszewski street: a) plan, b) cross-section (authors' drawings) 


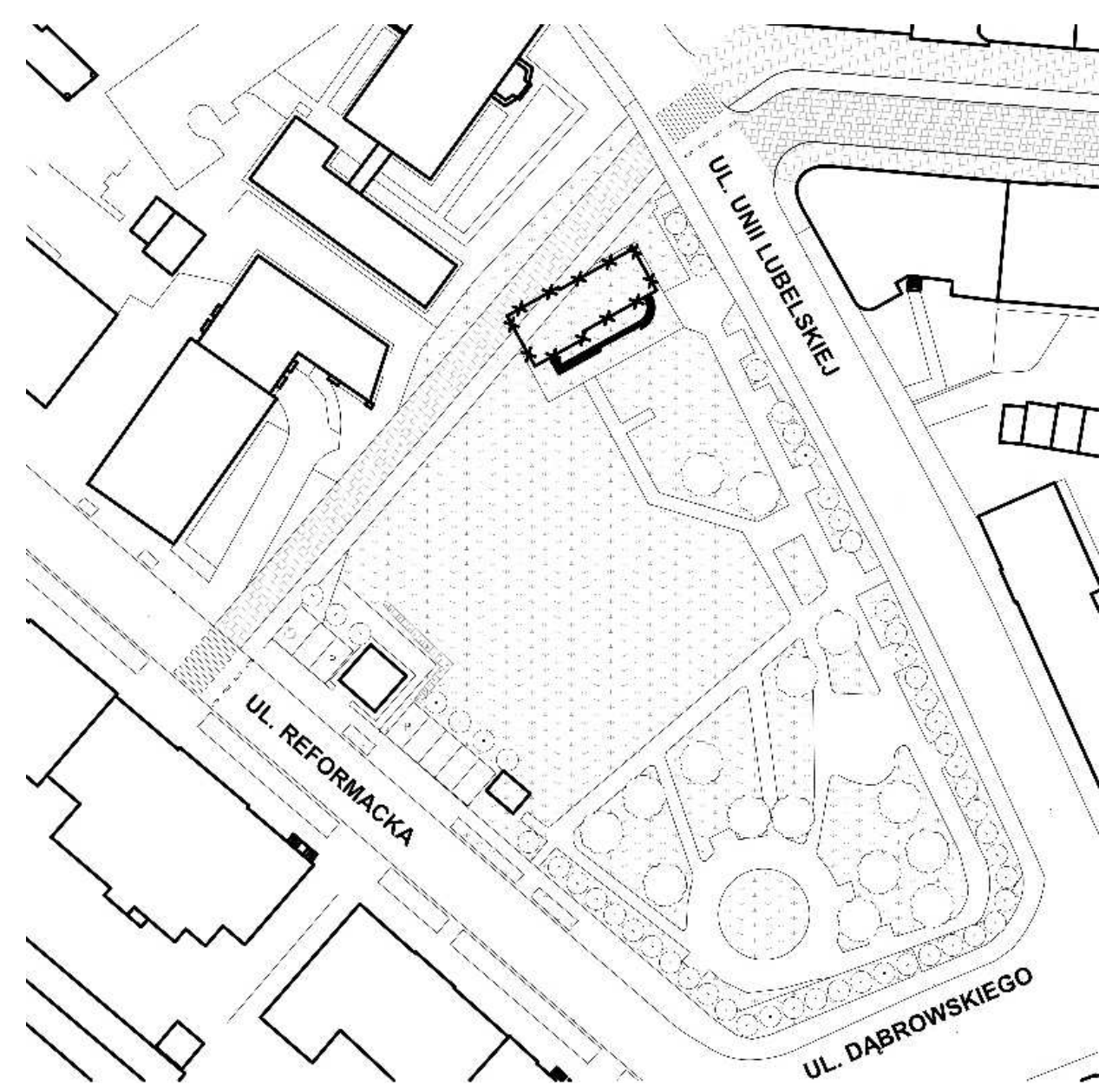

Rys. 6. Projekt zagospodarowania terenu między ulicami Unii Lubelskiej i Reformacką (rysunek autorów)

Fig. 6. Project of a land use between Lublin Union and Reformacka streets (authors' drawing)

\subsection{Modernizacja budynku piekarni przy ul. Reformackiej}

W stosunku do budynku piekarni mogą być brane pod uwagę dwie opcje: wyburzenie budynku lub jego części, albo adaptacja na bramę przejazdową, z zachowaniem w części obiektu funkcji piekarniczo-cukierniczej oraz handlowo-konsumpcyjnej. Więcej racji przemawia za drugim z rozwiązań. Pozostawienie bryły budynku nie zmieni charakteru terenu znajdującego się za nim, stanowiącego zamknięte wnętrze architektoniczne. Ponadto, piekarnia obdarzona jest swoistym ,geniusloci”, zaś wydobycie z zapomnienia takich miejsc jest wiodącą ideą całego projektu. Rozwiązaniem optymalnym byłaby taka adaptacja 
budynku, w następstwie której sień przejazdowa znalazłaby się w zachodniej jego części, z niej prowadziłoby wejście do części centralnej, w której odwiedzający mogliby obserwować przygotowywanie produktów, zaś sam zakup lub konsumpcja odbywałyby się, tak jak obecnie, w części wschodniej obiektu (rys. 7).

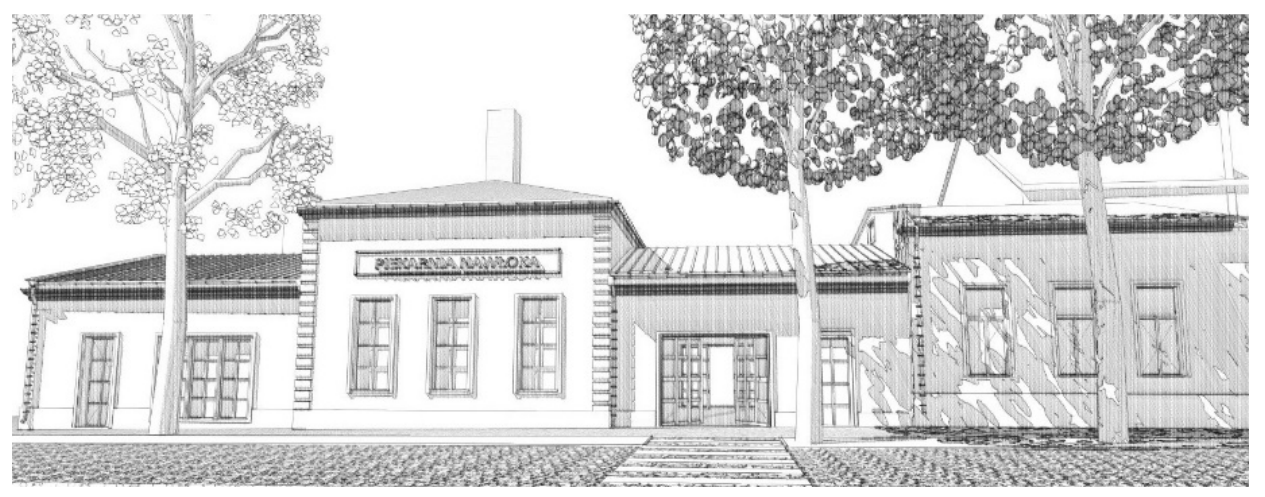

Rys. 7. Wizualizacja budynku piekarni po adaptacji na budynek przechodni (rysunek autorów)

Fig. 7. Visualization of a bakery building after adaptation to a gate building (authors' drawing)

\subsection{Adaptacja zabudowań na terenie wokół Kościoła Garnizonowego}

Wytyczenie ostatniego odcinka trasy po terenie okalającym kościół garnizonowy jest uzasadnione próbami przejęcia przez władze Rzeszowa znajdujących się na nim ruin po spalonym magazynie wojskowym i zorganizowania w odbudowanym obiekcie placówki o charakterze kulturalnym. Spośród kilku przeznaczeń najczęściej wymieniana jest funkcja galerii sztuki współczesnej lub osiedlowego domu kultury. Istnieją projekty adaptacji budynku na taki cel opracowane przez studentów Politechniki Rzeszowskiej [13]. Niektóre prace obejmują dodatkowo studium zagospodarowania terenu pomiędzy wymienionym budynkiem, kościołem i Ogrodem Miejskim [1]. Obecność placówki kulturalnej, wymaga wykreowania w jej sąsiedztwie pewnego obszaru przestrzeni publicznej. Przebiegający obok trakt spacerowy, integrujący całościowo przestrzeń publiczną historycznej części Rzeszowa, spełniałby tę rolę znakomicie.

W stosunku do usytuowanego na krańcu zaprojektowanej trasy jednokondygnacyjnego budynku magazynu przedkłada się propozycję jego adaptacji na budynek wejściowy do Ogrodu Miejskiego, w którym byłyby zlokalizowane toalety oraz wystawa ukazująca historię ogrodu, a w miarę możliwości kolejna na trasie kawiarnia. Wobec planów ogrodzenia ogrodu, w budynku mogłaby znaleźć się siedziba ochrony. Warunki przestrzenne stwarzają możliwość połą- 
czenia terenu okołokościelnego z ogrodem, również z ominięciem budynku magazynu, co należy wykorzystać dla wytyczenia tamtędy ścieżki rowerowej.

\section{Podsumowanie}

Realizacja opisanej w artykule koncepcji jest w stanie, zdaniem autorów, skutecznie powiększyć obszar przestrzeni publicznej w Rzeszowie i podnieść jej jakość, ze względu na integralne włączenie terenu o unikalnych wartościach przyrodniczych i krajobrazowych, jakimi charakteryzuje się Ogród Miejski. Autorzy są świadomi trudności wiążących się z realizacją niektórych zamierzeń, wynikających ze zróżnicowania stosunków własnościowych na analizowanym terenie oraz kosztów realizacji podziemnej infrastruktury komunikacyjnej, finansowych, jak i społecznych, związanych z utrudnieniami w trakcie budowy. Mimo to uważają, że zbudowanie nowoczesnego ośrodka miejskiego, zaspokajającego wszechstronne potrzeby mieszkańców wymaga śmiałych wyzwań, których efekty będą cieszyć przez wiele lat. Ukazanie ciągłości tożsamości miasta przez połączenie przeszłości, dnia dzisiejszego oraz przyszłości jest wartością, którą współczesna urbanistyka traktuje za jedną z fundamentalnych [12].

\section{Literatura}

[1] Andres B.: Projekt Centrum Sztuki Współczesnej w Rzeszowie, http://rzeszow.wyborcza.pl, (dostęp 08.05.2017).

[2] Brzeziński A. i inni: Poradnik: Organizacja przestrzeni ulic w obszarach śródmiejskich, Biuro Projektowo-Konsultingowe TransEko, Warszawa 2013.

[3] Chomiczewska K.: Podróż do przyszłości, czyli o przedwojennym modernizmie. Renowacje i Zabytki, 3(55)/2015, str. 137-148.

[4] Czarnota M.: Rzeszowskie ulice i okolice, MITEL, Rzeszów 2001.

[5] Gehl J.: Miasta dla ludzi, Wydawnictwo RAM, Kraków 2014.

[6] Hennig W.: Rzeszowski alfabet miejsc często już zapomnianych i osób z nimi związanych, Podkarpacki Instytut Książki i Marketingu, Rzeszów 2012.

[7] Gminna ewidencja zabytków Miasta Rzeszowa, Załącznik do Zarządzenia Nr VII /277/2015 Prezydenta Miasta Rzeszowa z dnia 16 lipca 2015 roku.

[8] Kotula F.: Tamten Rzeszów, MITEL, Rzeszów 2003.

[9] Krupa B.: Ogród Miejski w Rzeszowie, Zeszyty Naukowe Płd.-Wsch. Oddziału Polskiego Towarzystwa Inżynierii Ekologicznej, 12/2010, str. 47-52.

[10] Kultys R.: Historyczne centrum Rzeszowa - założenia strategii rewitalizacji, http://twinn.pl (dostęp 08.05.2017).

[11] Lorens P.: Definiowanie współczesnej przestrzeni publicznej. [w:] Problemy kształtowania przestrzeni publicznych (red. P. Lorens, J. Martyniuk-Pęczek), Wydawnictwo Urbanista, Gdańsk 2010, str. 6-20.

[12] Nowa Karta Ateńska 2003 - wizja miast XXI wieku. Towarzystwo Urbanistów Polskich 2003. 
[13] Prokop A.: Rewaloryzacja ruin przy ulicy Reformackiej w Rzeszowie na Ośrodek Kultury, Praca dyplomowa magisterska, Rzeszów 2016.

[14] Prokopska A.: Zastosowanie metody analizy morfologicznej w projektowaniu architektonicznym na przykładzie twórczości Le Corbusiera, Oficyna Wydawnicza Politechniki Rzeszowskiej, Rzeszów 1997.

[15] Prokopska A.: Metodologia projektowania architektonicznego: fazy wstępne procesu architektonicznego, Oficyna Wydawnicza Politechniki Rzeszowskiej, Rzeszów 2015.

[16] Szymczak-Hoff J.: Życie towarzyskie i kulturalne Rzeszowa w dobie autonomii Galicji, Krajowa Agencja Wydawnicza, Rzeszów 1993.

[17] Uruska-Suszek D: Nowe spojrzenie na Park Miejski w Rzeszowie, Czasopismo Techniczne 1A/1998, str. 142-146, Wydawnictwo Politechniki Krakowskiej.

\section{THE CONCEPT OF INTEGRATION OF THE "MUNICIPAL GARDEN" IN RZESZÓW WITH THE PUBLIC SPACE OF THE OLD CITY}

\section{S u m m a r y}

The paper presents the concept of broadening the space of social activity in Rzeszów, which includes the Rynek, Kosciuszko and May 3 streets, as well as the Lubomirskich and Pod Kasztanami alleys, by incorporating into it the Municipal Garden on the Dąbrowskiego street and connecting these two zones by walking trail. The concept has been developed in the aim of including to the area of heavily exploited public space, poorly noticeable and near areas, characterized by a similar cultural landscape.The route of the designed walking trail is planned to be run along Kraszewski Street, and after crossing Unii Lubelskiej street, perpendicularly to Reformacka Street, and next straight ahead towards Municipal Garden. The Municipal Garden has been analysed in the work, including its social role in the past, infrastructural transformations and the natural and landscape values that it presents nowadays. The article presents a list of plans for changes in the urban space of Rzeszów, aimed at incorporating the Municipal Garden into a homogenous public space. The key element of the project is the weakening of the pedestrian and bicycle obstacle of Lisa-Kuli street, by transferring part of the car traffic to a tunnel built under the existing carriageway. The project of extending the walking route in the area of the historic centre meets he needs of the city of Rzeszów. Due to development in recent decades and an increase in the number of inhabitants, the city suffers from a deficit of public space, suitable for the realization of inhabitants' social activity, and shaping of their identity and sense of belonging to the local community.

Keywords: Rzeszów, public space, urban layout, revaluation, revitalization, cultural landscape

Przestano do redakcji: 09.06.2017 $r$.

Przyjęto do druku: 01.09.2017 r. 